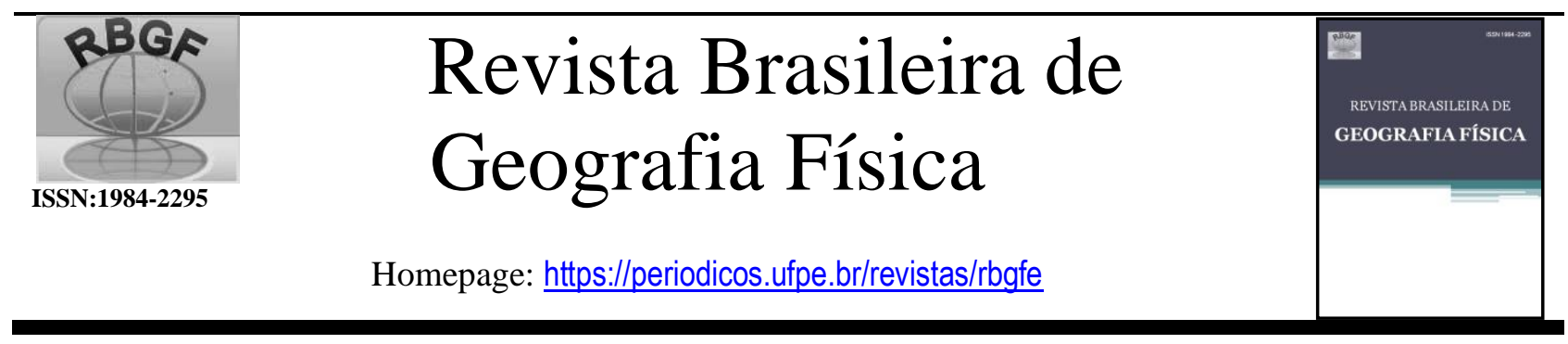

\title{
Identificação e Delimitação de Unidades de Paisagem do Município de Baía Formosa $(\mathbf{R N})^{1}$
}

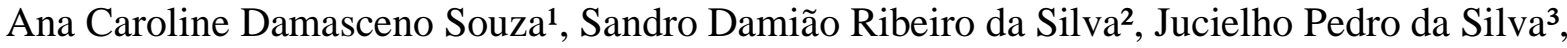 Marco Túlio Mendonça Diniz ${ }^{4}$.}

${ }^{1}$ Mestranda do Programa de Pós-graduação e Pesquisa em Geografia da Universidade Federal do Rio Grande do Norte. E-mail: carolsouza.geo@gmail.com.

${ }^{2}$ Doutorando do Programa de Pós-graduação e Pesquisa em Geografia da Universidade Federal do Rio Grande do Norte. E-mail: sandro@ comperve.ufrn.br.

${ }^{3}$ Mestrando do Programa de Pós-graduação em Geografia - GEOCERES do Centro de Ensino Superior do Seridó, campus Caicó, da Universidade Federal do Rio Grande do Norte. E-mail: jucyelho@ @otmail.com. ${ }^{4}$ Prof. Dr. do Programa de Pósgraduação e Pesquisa em Geografia da Universidade Federal do Rio Grande do Norte. E-mail: tuliogeografia@ gmail.com.

Artigo recebido em 24/06/2019 e aceito em 24/12/2019

\section{R E S U M O}

As Unidades de Paisagem são áreas homogêneas, com características naturais semelhantes, sendo o resultado da interação entre os agentes bióticos, abióticos e antrópicos da Paisagem. Para que elas possam ser operacionalizadas e discutidas, pode-se lançar mão da concepção geossistêmica, que é responsável pela fomentação de análises geográficas que consideram as múltiplas interconexões existentes no todo global. Tendo essas assertivas como válidas, esta pesquisa tem como objetivo a identificação, delimitação e descrição das Unidades de Paisagem do município de Baía Formosa (RN). Para sua realização, executou-se o mapeamento da área, baseado em critérios fisionômicos, valendo-se da escala das geofácies (1:25.000). Ademais, além da interpretação de imagens de satélite, foi realizado trabalho de campo para validação dos resultados prévios. Entre os resultados, destacam-se, nas Unidades de Paisagem, uma região natural, denominada de "Planícies e Planaltos Sedimentares Úmidos e Subúmidos"; dois geocomplexos, a saber: "Planícies Costeiras Úmidas" e "Tabuleiros Costeiros Úmidos", que, por sua vez, foram compartimentados em dez e cinco geofácies, respectivamente. Predominou, no município, a geofácie Agricultura Temporária (Cana-de-açúcar), a qual foi mapeada em 48,94\% da área municipal, o que equivale a $125,05 \mathrm{~km}^{2}$. Na sequência, surge a Mata de Restinga no Tabuleiro com 13,80\% da área e 35,27 km². Em seguida, há a Planície Flúvio-Marinha com Manguezal, que se situa em 13,46\% do território com uma área de $34,40 \mathrm{~km}^{2}$. Portanto, a utilização das geotecnologias possibilitou um rico detalhamento de informações a qual a escala utilizada abrange, fornecendo subsídios ao ordenamento territorial.

Palavras-chave: Abordagem Geossistêmica; Unidades de Paisagem; Baía Formosa - RN.

\section{Identification and Delimitation of Landscape Units in the Municipality of Baía Formosa (RN)}

\section{A B S T R A C T}

The Landscape Units are homogeneous areas, with similar natural characteristics, being the result of the interaction between the biotic, abiotic and anthropic agents of the Landscape. So that they can be operationalized and discussed, one can draw on the geosystemic conception, which is responsible for fostering geographic analyzes that consider the multiple interconnections existing in the global whole. Having these assertions as valid, this research has as objective the identification, delimitation and description of the Landscape Units of the municipality of Baía Formosa (RN). For its accomplishment, the mapping of the area was executed, based on physiognomic criteria, using the scale of the geofacies $(1: 25,000)$. In addition, besides the interpretation of satellite images, field work was carried out to validate the previous results. Among the results, stand out in the Landscape Units a natural region called "Plains and Plateaus Sedimentary Humid and Subhumid"; two geocomplexes, namely: "Humid Coastal Plains" and "Humid Coastal Tablelands", which, in turn, were compartmentalized into ten and five geofacies, respectively. Predominated, in the municipality, the geofacie Temporary Agriculture (Sugar Cane), which was mapped in 48.94\% of the municipal area, which is equivalent to 125.05 $\mathrm{km}^{2}$. In the sequence, the Restinga Forest on the Tableland with $13.80 \%$ of the area and $35.27 \mathrm{~km}^{2}$. Then, there is the Fluvial-marine Plain with Mangrove, which is situated in $13.46 \%$ of the territory with an area of $34.40 \mathrm{~km}^{2}$. Therefore,

\footnotetext{
1 Trabalho financiado pela CAPES através de bolsa para a primeira autora.
} 
the use of geotechnologies made it possible a rich information detail to which the scale used covers, providing subsidies to the spatial planning.

Keywords: Geosystemic Approach; Landscape Units; Baía Formosa - RN.

\section{Introdução}

O pensamento sistêmico, que está em baila neste artigo, foi remodelado paulatinamente ao longo da história, ganhando contornos sistemáticos no decorrer de séculos hodiernos. A Teoria Geral dos Sistemas (TGS) foi proposta pelo biólogo austríaco Ludwig von Bertalanffy, em caráter inaugural, através de discussões realizadas num seminário de Filosofia em Chicago, nos Estados Unidos da América (EUA) (Marques Neto, 2008).

No tocante aos efeitos da TGS no âmbito geográfico, realça-se a concepção geossistêmica, defendida no presente artigo. Desenvolvida pelo cientista soviético Viktor Sochava, a partir da criação do conceito de Geossistema, foi disseminada no Ocidente por Bertrand 1972 e aplicada por Tricart 1977, Bolós 1981 e Christofoletti 1999. A concepção geossistêmica trouxe relevantes avanços na Geografia Física, possibilitando uma satisfatória análise das relações mútuas e integradas entre os aspectos naturais e sociais. O termo específico Geossistema surgiu, originalmente, no artigo intitulado "The Definition of Some Concepts and Terms in Physical Geography", publicado no ano de 1963 em território soviético (Sochava, 1963). O significado atribuído ao vocábulo o designa como uma área da superfície terrestre, mais ou menos homogênea, em que se distinguem relações entre os componentes da natureza.

A Paisagem, por sua vez, é um conceito fundante da ciência geográfica e, como tal, é alvo de definições e reflexões há várias décadas, por parte, principalmente, da Geografia Física. A partir da segunda metade do século XX, este conceito adquiriu importância capital, pois parte dos estudos propostos nesta época consideravam-na também como a categoria de análise fundamental dos estudos da vertente física da Geografia. No artigo que está escrito nestas laudas, foi realizada uma associação entre o Geossistema e a Paisagem a fim de ser compreender o recorte estabelecido para a análise: o município de Baía Formosa (RN).

Dito isto, é preciso esclarecer que a proposta taxonômica de Bertrand 1972, para o estudo global da Paisagem é mais bem estruturada que as proposições explicitadas por Sochava e seus discípulos e, por isso, ela foi aplicada no presente trabalho. Diferentemente da concepção teórica, Sochava não conseguiu estabelecer uma proposição escalar tão eficaz como o aludido geógrafo francês que, além dessa assertiva, teve o mérito de integrar a Paisagem com a escala numa tentativa de operacionalização metodológica.

Bertrand 2004, esboçou uma metodologia peculiar na classificação paisagística. Segundo tal metodologia, a taxonomia das paisagens é dividida em Zonas, Domínios e Regiões Naturais (unidades superiores) e Geossistemas (mais tarde denominados de Geocomplexos), Geofácies e Geótopos (unidades inferiores), considerando a escala espaço-temporal, de Cailleaux e Tricart 1956. Tal subdivisão acabou por eliminar incorreções praticadas à época por geógrafos do mundo inteiro e é tomada como norte neste artigo.

Enfatizando a discussão acerca da taxonomia proposta por Bertrand, como afirmam Diniz, Oliveira e Medeiros 2015, o Geossistema está "acima" de uma simples unidade taxonômica, estando próximo de uma categoria de análise da Geografia (ideia que se coaduna aqui). Assim, estes autores ressaltam a noção de Geocomplexo, proposta, de maneira não contumaz, pelo próprio Bertrand (Bertrand e Bertrand, 2007), como mais apropriada para a taxonomia de paisagens.

Entende-se, aqui, para além disso, que as Unidades de Paisagem são definidas e classificadas de acordo com a homogeneidade das características contidas na Paisagem e da escala de análise, sendo o resultado das interações naturais e antrópicas, que mutualmente moldam o Espaço Geográfico (Ross, 2009).

Faz-se necessário destacar que o aspecto fisionômico, relacionado ao termo fácie, foi o principal fator delimitador das Unidades de Paisagem aqui analisadas. Assim, na taxonomia proposta por Bertrand 2004, escolheu-se a geofácie como sendo o táxon a ser trabalhado com mais acurácia neste trabalho. $\mathrm{O}$ francês define a geofácie como sendo um setor fisionomicamente homogêneo, onde se desenvolve uma mesma fase da evolução geral do geocomplexo. Além disso, variáveis da Paisagem, como a geomorfologia, foram consideradas na análise, devido a maior estabilidade na escala têmporo-espacial dos níveis taxonômicos, em detrimento da vegetação que se encontra bastante modificada pela ação humana, por meio do uso e ocupação do solo em atividades sociais e econômicas.

Para representação espacial/cartográfica do mapeamento, as Unidades de Paisagem foram vetorizadas em escala de geofácie (1:25.000), considerando principalmente o aspecto fisionômico homogêneo (como já mencionado), no qual a Paisagem passou por processos semelhantes 
em sua formação e modificação provenientes dos agentes naturais e antrópicos (Bertrand, 1972). Portanto, o objetivo deste trabalho é identificar, delimitar e descrever as Unidades de Paisagem do município de Baía Formosa (RN), considerando a escala taxo-corológica das geofácies.

\section{Material e métodos}

\section{Procedimentos metodológicos}

Os procedimentos adotados para realização do presente trabalho consistiram, inicialmente, em um levantamento teórico acerca dos autores utilizados (Sochava, 1963; Bertrand, 1972; Tricart, 1977; Bertrand, 2004; Bertrand e Bertrand, 2007; Ross, 2009; Diniz, Oliveira e Medeiros, 2015; Silva, 2018; Diniz e Oliveira, 2018). Além disso, se utilizou de pesquisa acadêmica, científica e cartográfica da área estudada (Fernandes, 2006; Oliveira, 2011; Silva, 2013).

Foi utilizada, como base, a compartimentação do estado do Rio Grande do Norte a nível taxonômico dos geocomplexos (Diniz e Oliveira, 2018), além da análise dos mapas temáticos do estado de Geologia (Angelim, Medeiros e Nesi, 2006), Geomorfologia (Diniz, et al., 2017), Climatologia (Diniz e Pereira, 2015), Vegetação e Solos do projeto RADAMBRASIL, folha Jaguaribe Natal (Brasil, 1981) para subsidiar as hipóteses da classificação de cada Unidade da Paisagem.

Em seguida, foi realizada a delimitação e espacialização da compartimentação das Unidades de Paisagem, onde foi utilizado o software ArcGIS 10.4 (Versão Acadêmica). Devido a necessidade da utilização de imagens de melhor resolução, com pouca ou nenhuma influência de nuvens, destacase o processo de vetorização manual de Unidades de Paisagem, usando como base imagens extraídas da seção Basemap do ArcGIS. Estas imagens são oriundas do satélite WorldView 2, de 24 de maio de 2017, com resolução espacial de $0,5 \mathrm{~m}$ e acurácia posicional de 10,2 m.

Buscando a interpretação visual destas imagens a partir do método indutivo, foi usada uma maneira mais sofisticada deste método, denominada Inferência à Melhor Explicação (IME), a qual combina a prática inferencial com a explicativa (Diniz e Silva, 2018). Ademais, houve a relação entre a interpretação visual com os objetos, classificando, a partir de diferentes critérios, áreas homogêneas, como Panizza e Fonseca 2011, fizeram, elencando os seguintes elementos: forma, tonalidade, localização, textura e estrutura do objeto na Paisagem, em consonância com as características de cada geofácie.
As cores da representação das geofácies no mapa foram selecionadas utilizando escalas de cores monocromáticas, seguindo as matrizes dos geocomplexos definidas por Diniz e Oliveira, 2018, sendo estas em verde em tom mais claro e mais escuro, respectivamente, as Planícies Costeiras Úmidas R0G240B0 e os Tabuleiros Costeiros Úmidos R0G115B0. Para a nomenclatura, foram utilizados critérios de geomorfologia, vegetação e ocupação do solo, ressaltando o aspecto predominante da paisagem. Um exemplo disto é a Planície Flúvio-Marinha com Manguezal, o qual está localizado na interface costeira e continental, em área de estuário com direta influência marinha, desenvolvendo o ecossistema de manguezal.

Foram, ainda, realizados trabalhos de campo em busca da identificação e caracterização das diferentes Unidades de Paisagem, primeiramente para reconhecimento do ambiente a qual seria mapeado, e, posteriormente, com o mapa prévio em mãos (vetorizado), para validação dos resultados. Para estas atividades, contou-se com o auxílio de 1 aparelho Global Navigation Satellite System (GNSS) e um Veículo Aéreo Não Tripulado (VANT) de modelo Phantom Advanced 3 para registro fotográfico e resolução de dúvidas em locais de difícil acesso. Após isso, houve o processo de finalização, em gabinete, da revisão dos mapas e a construção de uma discussão teórica e empírica dos resultados da pesquisa.

\section{Área de Estudo}

A denominação Baía Formosa originou-se por situar-se em uma enseada denominada localmente por b aía, pertencente à microrregião do Litoral Sul, distante aproximadamente $100 \mathrm{~km}$ da capital do estado, Natal. O acesso é realizado através da BR - 101 (trecho Natal - João Pessoa) e da RN - 062 (em direção à sede municipal).

Baía Formosa faz fronteiras com os municípios de Canguaretama (RN) e Mataraca (PB) e sua população estimada em 2018 é 9.218 pessoas (IBGE, 2018). O município abrange a maior área contínua de Mata Atlântica do estado (2.039,93 ha), comportando a Reserva Particular do Patrimônio Natural (RPPN) - Mata Estrela (ICMBio, 2018).

O município (Figura 1) teve sua origem em um núcleo de pescadores que se organizaram em torno do movimentado porto de embarcações, situado no Oceano Atlântico, após a extração do pau-brasil, em meados do século XVIII. A área ficou conhecida como zona de pesca e praia de pescadores, também sendo utilizada para veraneio das famílias Albuquerque Maranhão e de fazendeiros ricos das redondezas (Morais, 1998; 
Lima, 2004). Posteriormente, com a expansão da cana-de-açúcar (cultura temporária) como atividade econômica, houve o avanço da monocultura (que permanece até hoje), da pesca, da colheita do côco-da-baía (cultura permanente) e da atividade turística um pouco rústica, na qual a praia do pontal é palco de campeonatos amadores e profissionais de surf (Soares, 2013).

O município está situado geologicamente entre o embasamento sedimentar do Grupo Barreiras e depósitos sedimentares holocênicos, estando inseridas na Zona Intertropical e no Domínio Morfoclimático denominado "Domínio Tropical da Mata Atlântica", de acordo com a classificação dos Domínios Morfoclimáticos proposta por Aziz Ab'Saber 2003. A área se encontra na região natural "Planícies e planaltos sedimentares úmidos e subúmidos" que divide-se em 2 (dois) geocomplexos: "Planícies costeiras úmidas" e "Tabuleiros costeiros úmidos" (Diniz; Oliveira, 2018), área em que a seguir, serão evidenciados o táxon das geofácies.
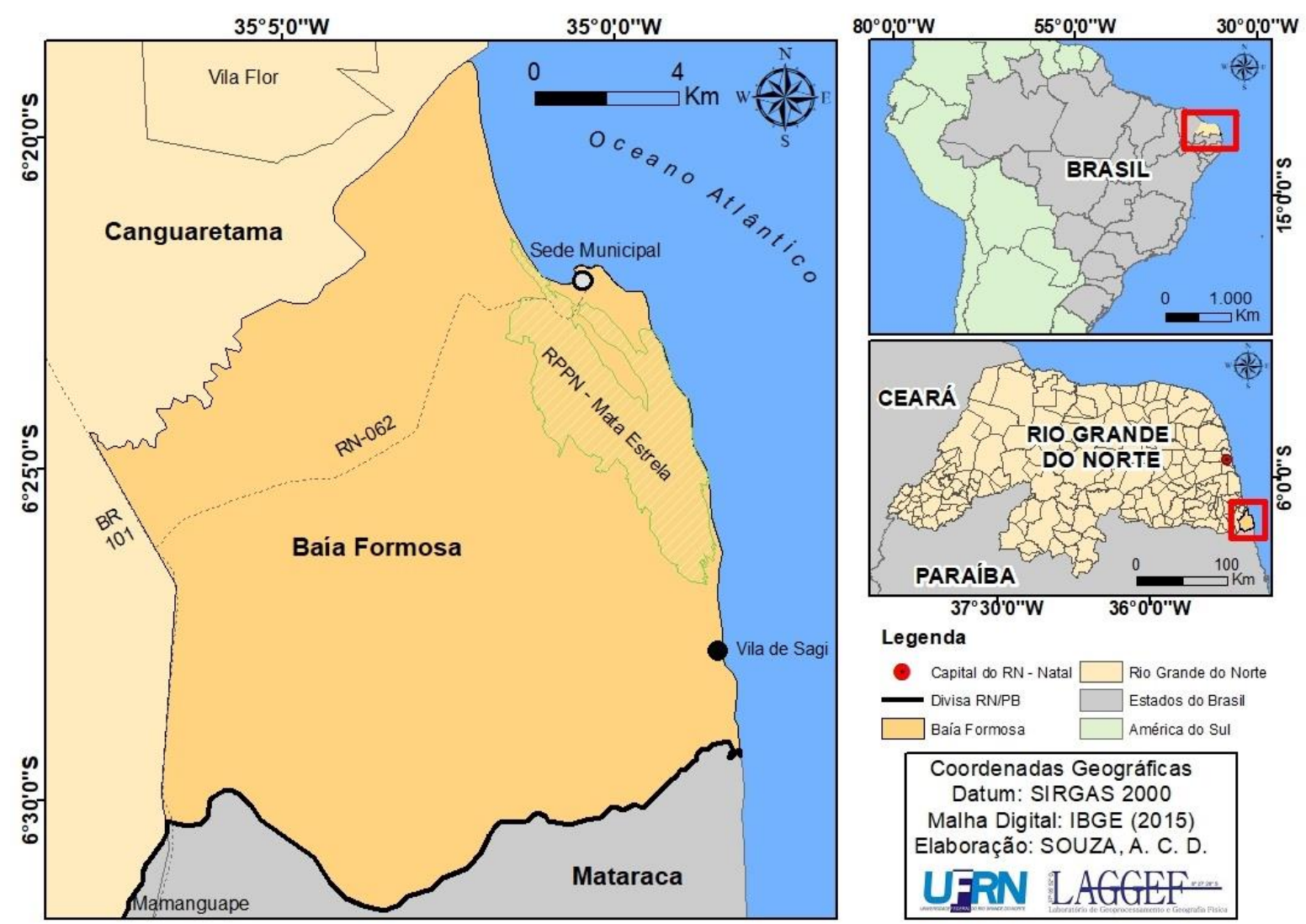

Figura 1 - Mapa de localização de Baía Formosa (RN).

\section{Resultados e discussão}

Foram delimitadas 15 (quinze) geofácies no município de Baía Formosa (RN) (Figura 2), sendo que o que geocomplexo "Planícies costeiras úmidas" subdivide-se em 10 (dez) geofácies: "Planície Flúvio-Marinha com Manguezal", "Planície Flúvio-Marinha com Solo Exposto", "Mata de Restinga em Paleodunas", "Paleodunas
Degradadas", "Dunas Móveis", "Dunas Semifixas", "Dunas Fixas", "Carcinicultura", "Praia e Pós-praia" e "Edificações". Já na subdivisão dos "Tabuleiros costeiros úmidos", encontram-se 5 (cinco) geofácies: "Agricultura Permanente", "Agricultura Temporária", "Mata de Restinga no Tabuleiro", "Quebra-ventos" e "Edificações" (Quadro 1). 


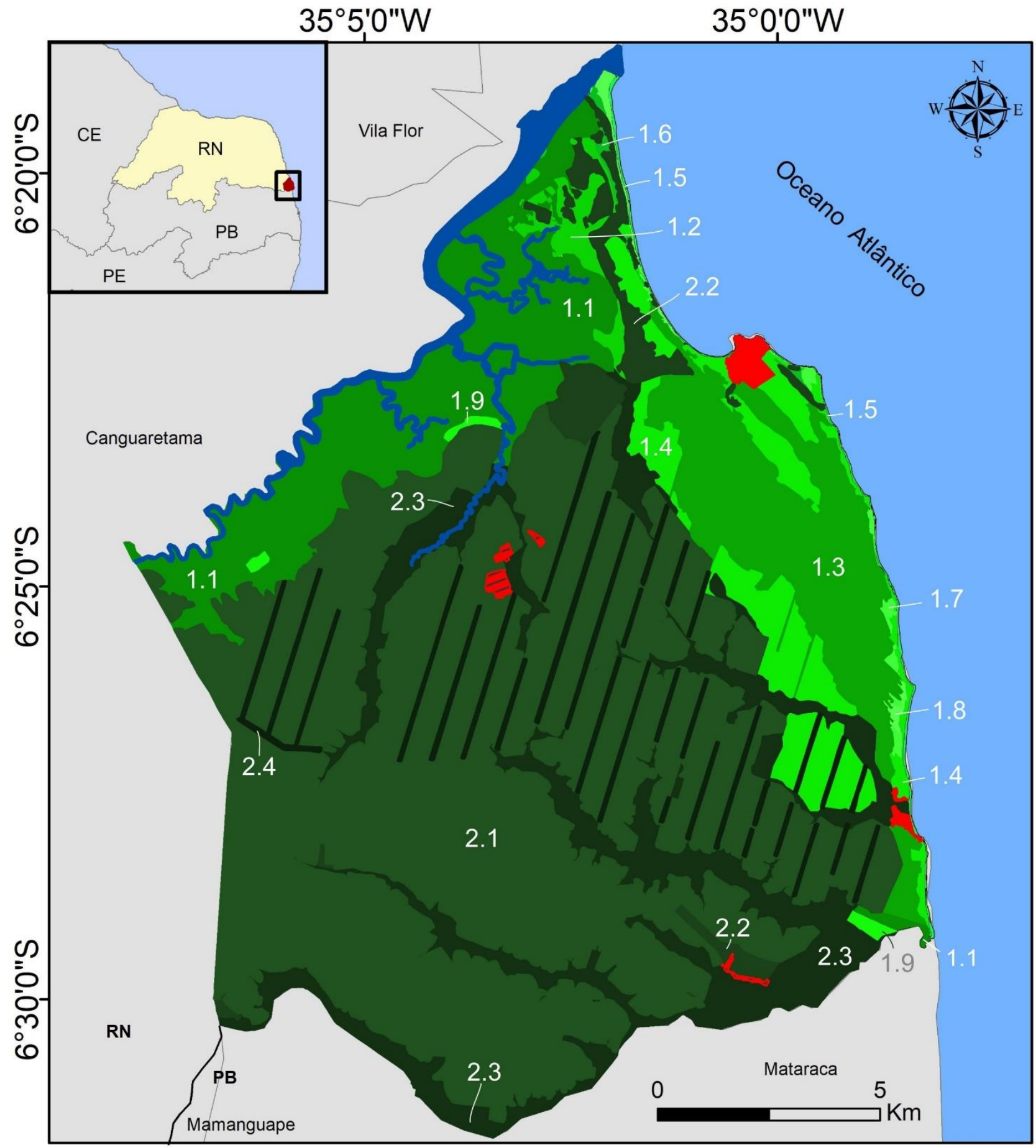

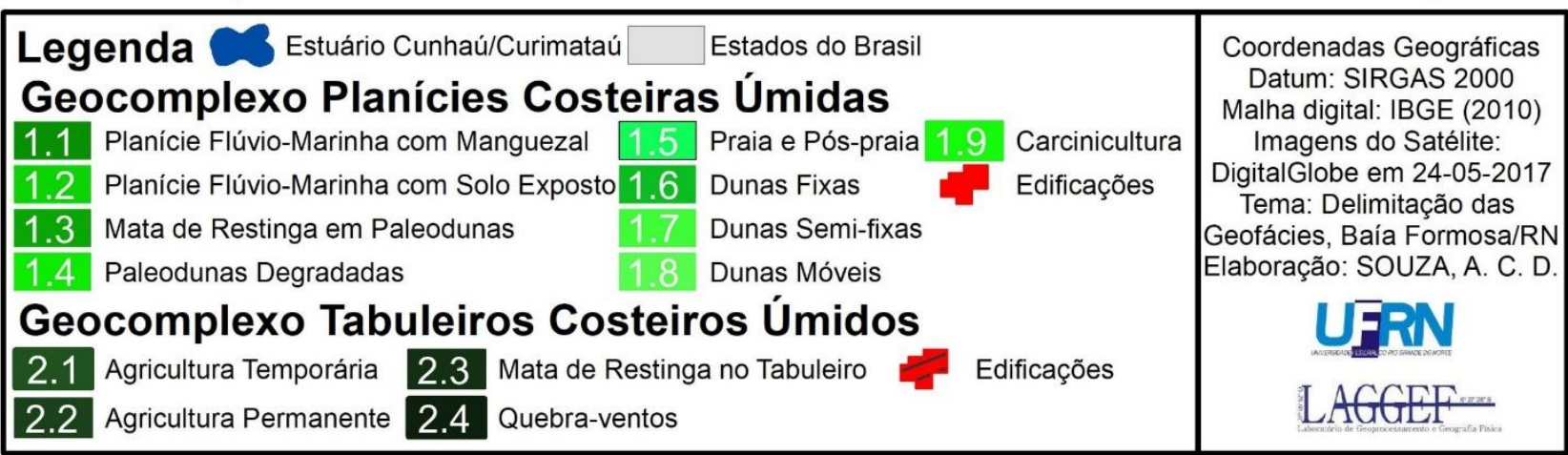

Figura 2 - Mapa das geofácies do município de Baía Formosa (RN). 
Quadro 1 - Compartimentação das Unidades de Paisagem de Baía Formosa (RN).

\begin{tabular}{|c|c|c|c|c|c|}
\hline ZONA & $\begin{array}{c}\text { DOMÍNIOS } \\
\text { MORFOCLI- } \\
\text { MÁTICOS }\end{array}$ & $\begin{array}{l}\text { REGIÕES } \\
\text { NATURAIS }\end{array}$ & $\begin{array}{l}\text { GEOCOM- } \\
\text { PLEXOS }\end{array}$ & GEOFÁCIES & $\begin{array}{l}\text { ÁREA TOTAL } \\
\left(\mathrm{KM}^{2} / \%\right)\end{array}$ \\
\hline \multirow{17}{*}{ 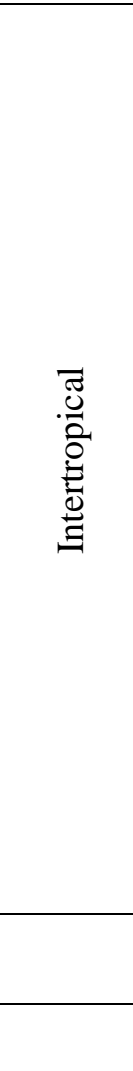 } & \multirow{15}{*}{$\begin{array}{c}\text { Domínio } \\
\text { Tropical da } \\
\text { Mata Atlântica }\end{array}$} & \multirow{15}{*}{$\begin{array}{l}\text { Planícies e } \\
\text { planaltos } \\
\text { sedimentares } \\
\text { úmidos e } \\
\text { subúmidos }\end{array}$} & \multirow{10}{*}{$\begin{array}{l}\text { Planície } \\
\text { Costeira } \\
\text { Úmida }\end{array}$} & $\begin{array}{l}\text { 1.1 Planície Flúvio-Marinha } \\
\text { com Manguezal }\end{array}$ & $34,40(13,46 \%)$ \\
\hline & & & & $\begin{array}{l}\text { 1.3 Mata de Restinga em } \\
\text { Paleodunas }\end{array}$ & $21,59(8,45 \%)$ \\
\hline & & & & 1.4 Paleodunas Degradadas & $14,16(5,54 \%)$ \\
\hline & & & & Edificações & $4,05(1,58 \%)$ \\
\hline & & & & $\begin{array}{l}\text { 1.2 Planície Flúvio-Marinha } \\
\text { com Solo Exposto }\end{array}$ & $2,89(1,13 \%)$ \\
\hline & & & & 1.8 Dunas Móveis & $0,71(0,28 \%)$ \\
\hline & & & & 1.5 Praia e pós-praia & $0,99(0,39 \%)$ \\
\hline & & & & 1.7 Dunas Semi-fixas & $0,62(0,24 \%)$ \\
\hline & & & & 1.9 Carcinicultura & $0,62(0,24 \%)$ \\
\hline & & & & 1.6 Dunas Fixas & $0,45(0,18 \%)$ \\
\hline & & & \multirow{5}{*}{$\begin{array}{l}\text { Tabuleiros } \\
\text { Costeiros } \\
\text { Úmidos }\end{array}$} & 2.1 Agricultura Temporária & $125,05(48,94 \%)$ \\
\hline & & & & $\begin{array}{l}\text { 2.3 Mata de Restinga no } \\
\text { Tabuleiro }\end{array}$ & $35,27(13,80 \%)$ \\
\hline & & & & 2.2 Agricultura Permanente & $7,32(2,86 \%)$ \\
\hline & & & & 2.4 Quebra-ventos & $3,38(1,32 \%)$ \\
\hline & & & & Edificações & $0,49(0,19 \%)$ \\
\hline & & & & $\begin{array}{l}\text { Estuário do rio } \\
\text { Cunhaú/Curimataú }\end{array}$ & $3,54(1,39 \%)$ \\
\hline & & & & Total & 255,53 \\
\hline
\end{tabular}

Geocomplexo Planície Costeira Úmida

Planície Flúvio-Marinha com Manguezal

Planície Flúvio-Marinha é a denominação utilizada para definir a área alagadiça de influência marinha. Tais coberturas sedimentares têm origem no período quaternário, mais especificamente no holoceno (Diniz, et al., 2017). Estas áreas de transição entre ambientes aquáticos e terrestres são enquadrados como uma área úmida, sendo inundados periodicamente, regidos pelas marés ou por eventos extremos como chuvas intensas provocadoras de pulsos de inundação (Junk et al., 2014; Souza, et al., 2017).

O ecossistema de Manguezal compõe esta paisagem, estando localizado no extremo norte do município (área limítrofe com Canguaretama) no estuário do rio Cunhaú/Curimataú (Figura 3). Estes ambientes têm solos hidromórficos, lamosos e alta produtividade de nutrientes e matéria orgânica, sendo classificados como gleissolos tiomórficos. Sua vegetação é halófila, adaptada a salinidade e possui caráter arbustivo-arbóreo e frondoso, alcançando a altura entre 10 e 15 metros (Souza, 2004; EMBRAPA, 2013).

Uma das adaptações do mangue às condições mencionadas anteriormente refletem em aspectos na paisagem, como a presença de plantas pneumatóforas, com raízes aéreas para o solo lamoso não interferir nas trocas gasosas, predominando, durante o estuário uma espécie dessa natureza, a Rhizophora mangle. Ademais, existem outras 4 (quatro) espécies na área de estudo, que desenvolveram, ao longo de sua evolução, estratégias para lidar com estas condições adversas, sendo estas, a Laguncularia racemosa, Avicennia germinans, Avicennia schaueriana e Conocarpus erectus (Silva, 2013).

Os manguezais são de extrema importância para a vida marinha e humana, visto que oferecem diversos serviços ecossistêmicos, servindo como berçário e refúgio para a reprodução de diversas espécies, como peixes, aves e crustáceos, além de auxiliar na estabilização dos sedimentos, reduzindo a ação dos processos erosivos (Costa, 2017). Para que estes ambientes sejam resguardados e continuem promovendo suas funções ambientais, e, de acordo com o novo Código Florestal, os manguezais estão enquadrados como Áreas de Preservação Permanente (APP) (Brasil, 2012). 


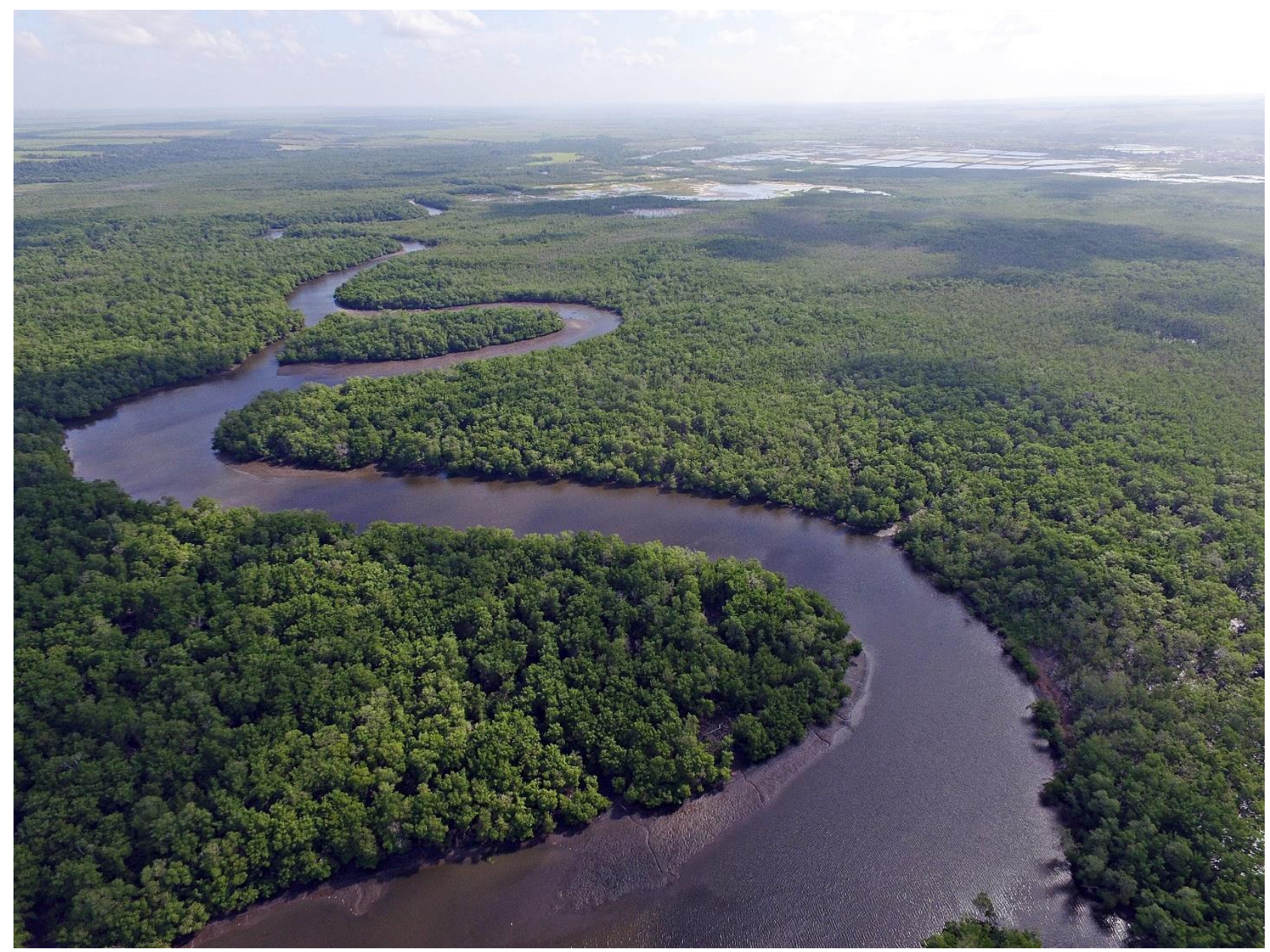

Figura 3 - Ecossistema de Manguezal no estuário do Rio Curimataú/Cunhaú (RN)..

Planície Flúvio-Marinha com Solo Exposto

Essas geofácies são semelhantes em geoforma e litologia à anterior, contudo foi degradada pela ação humana de desmatamento. Em Baía Formosa, estão presentes na fração setentrional do município, se entremeando na paisagem com os Manguezais que rodeiam a desembocadura do rio Curimataú (limite com o município de Canguaretama). Apesar de tradicionalmente ser uma geofácie de complicada delimitação, o mapeamento não encontrou dificuldades, uma vez que as imagens de satélite utilizadas foram de alta resolução, conforme fora descrito nos procedimentos metodológicos.

\section{Mata de Restinga em Paleodunas}

Esta geofácie está presente a leste do município, no sentido Norte-Sul, resguardando a área da RPPN - Mata Estrela (Figura 4) que é uma área privada, com 2.039,93 ha, ou 20,39 km². Foi mapeada em $21,59 \mathrm{~km}^{2}$. Tem por objetivo conservar a diversidade biológica, sendo definida como Reserva Legal de propriedade da Destilaria
Baía Formosa S/A. A Paisagem apresenta uma vegetação arbustiva-arbórea de predomínio da mata atlântica, com espécies diversificadas de outros biomas, como cerrado, e algumas cactáceas da Caatinga nas adjacências, possuindo um número menor de espécies do que as florestas ombrófilas densas, devido a degradação da área desde a colonização (Dorado et al., 2006). Ainda na mata de restinga, é possível observar uma camada superficial de serrapilheira, com folhas em decomposição no solo, e é habitat para diversas espécies da fauna e flora.

Devido a precipitação média anual superior a $1100 \mathrm{~mm}$, bem distribuída ao longo do ano, a área de Clima Tropical do Nordeste Oriental foi mapeada por Diniz e Pereira 2015, como de subdomínio climático úmido com 3 meses secos, o que propicia condições na região para dar suporte ao desenvolvimento desta vegetação, esta, por sua vez, evidencia o predomínio da pedogênese, sendo possível classificar o meio como estável na visão da ecodinâmica proposta por Tricart 1977. 


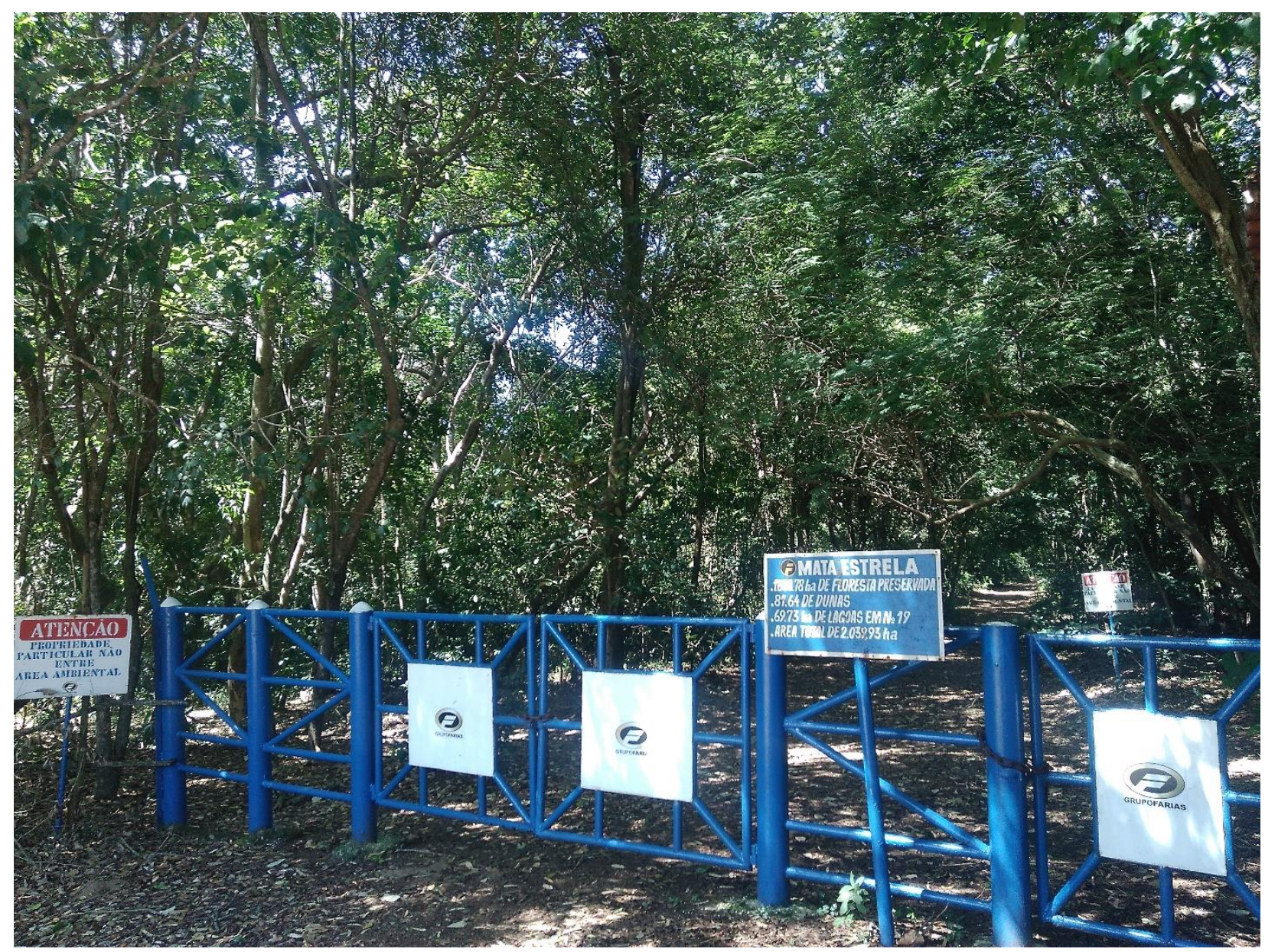

Figura 4 - RPPN Mata Estrela no município de Baía Formosa (RN).

\section{Paleodunas Degradadas}

Esta geofácie é caracterizada por dunas antigas com formação de neossolos quartzarênicos, além de ter coloração mais escura. Sua vegetação é predominantemente herbácea e com arbustos espaçados, situada em planícies costeiras úmidas onduladas, na qual o ecossistema sobre dunas está desenvolvendo o processo de edafização. Esta área foi degradada pela ação humana de desmatamento, já foi tomada por vegetação arbustivo-arbórea semelhante à da unidade anterior, sendo visualizadas na figura 5 as diferenças fisionômicas das unidades. Atualmente passa pelo processo de consolidação de neossolos quartzarênicos e estão localizadas próximo a faixa praial.

Com o olhar da teoria ecodinâmica de

Tricart 1977, pode-se considerar uma zona inserida intergrade em transição para a instabilidade, devido à degradação da vegetação. No entanto, as ações externas intempéricas, como a ação eólica, além da ação das ondas, causam a queda/desmoronamento das dunas. Especificamente na enseada, haviam casas, barracas e até empreendimento de pesca à beira mar, que foram retirados devido ao avanço do mar e os riscos expostos com os desmoronamentos. 


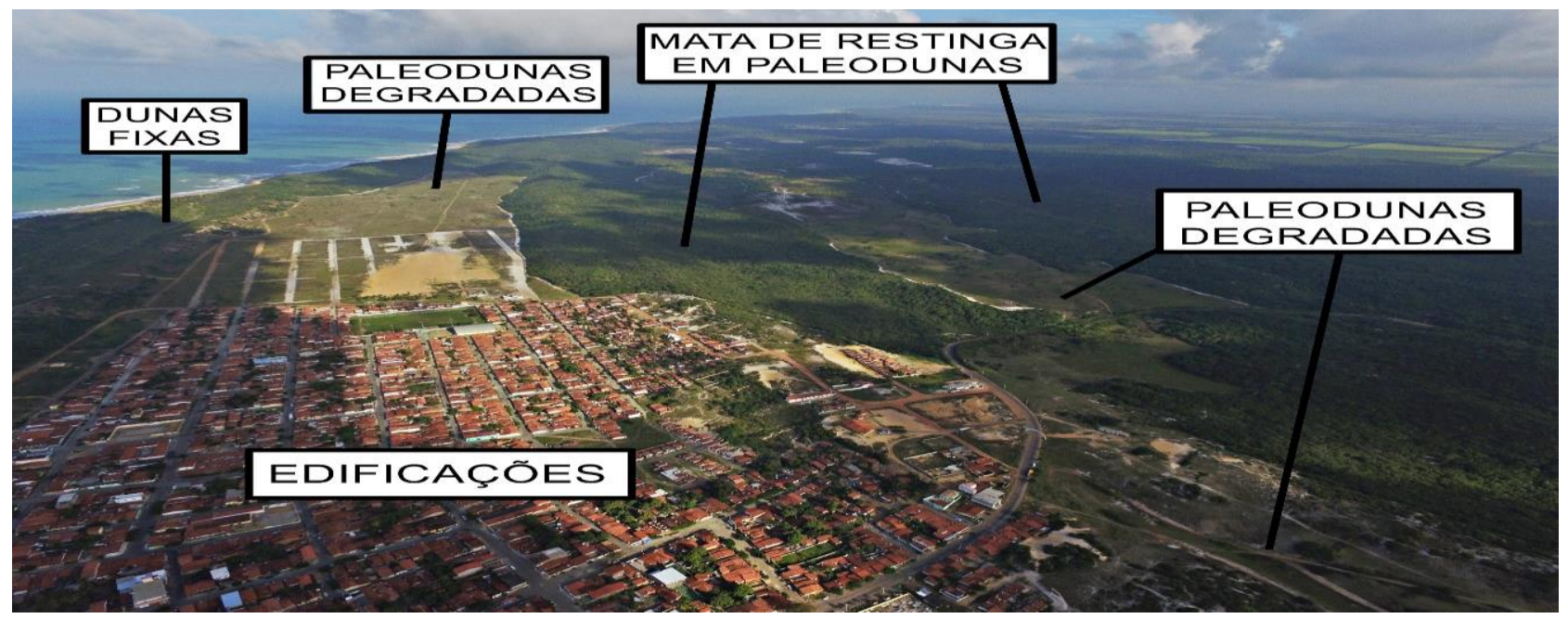

Figura 5 - Mosaico de paisagens no município de Baía Formosa (RN).

\section{Dunas Móveis}

O litoral oriental do Rio Grande do Norte foi classificado Diniz e Oliveira 2016 de Costa Mista de Dunas e Falésias, na qual o município Baía Formosa está inserido, este trecho intercala falésias do Grupo Barreiras com dunas em uma estreita faixa de terras próximas ao oceano. As Dunas Móveis, de idade holocênica, são fisionomicamente vistas na porção centro-leste do município, estando assentadas na direção NO-SE, semelhante a posição da linha de costa do litoral sul do estado do RN. São limitadas por Mata de Restinga em paleodunas, paleodunas degradadas e praia e pós-praia, estando situadas sempre em linha paralela à costa (Figura 6).

Tem sedimentos de origem marinha, sendo esbranquiçados e amarelados, bem selecionados, finos, redondos, parcialmente consolidados, os quais foram transportados pela ação eólica, que dispõe de velocidades consideráveis na área (Angelim, Medeiros e Nesi, 2006).

Tal geofácie ocorre em depósitos de areias quartzosas com ausência de solos, não tendo a vegetação como agente fixador de sua carga sedimentar. Os processos pedogenéticos são, destarte, inexistentes em grande escala, de modo que a morfogênese ganha sobressalto, tornando está geofácie, ecodinamicamente, muito instável. Além disso, as Dunas Móveis são importantes no que tange à recarga subterrânea de aquíferos. Por estas razões, o Código Florestal Vigente (Brasil, 2012) proíbe a ocupação humana.

\section{Dunas Semi-fixas}

As Dunas Semi-fixas estão em processo de transição entre as Dunas Móveis e as Dunas Fixas. Constituem-se em antigas Dunas Móveis, que passaram pelos diversos processos de transporte e deposição de sedimentos, além de processos pedogenéticos em pequena escala, originando solos jovens do tipo neossolos quartzarênicos. A vegetação, por sua vez, é o agente fixador em determinadas partes da geofácie. A vegetação que coloniza parte das Dunas Semifixas de Baía Formosa é herbácea ou arbustiva, sempre espaçada.

Esta unidade de paisagem se localiza em pequenas áreas encravadas entre Dunas Móveis (a leste) e Dunas Fixas (retaguarda a oeste), estando presentes em pequenas "manchas" da Paisagem. Também acompanham a disposição da linha de costa e os seus sedimentos são, em maioria, areias quartzosas, bem selecionadas e arredondadas. A sua formação, como nas outras dunas mencionadas, ocorreu em função da acumulação de sedimentos vindos de praias e da planície costeira, que está assentada sobre a Formação Barreiras. Os neossolos quartzarênicos compõem as Dunas Semi-fixas de Baía Formosa. Estes solos possuem susceptibilidade à erosão alta e os mesmos quase não possuem aptidão agrícola (EMBRAPA, 2013).

Na vertente ecodinâmica de Tricart 1977, as Dunas Semi-fixas são ambientes fortemente instáveis, devido à predominância dos processos morfogenéticos que podem ser agravados pela ocupação humana, a qual desperta forte vulnerabilidade. Os processos morfogenéticos não são tão amplos como nas Dunas Móveis, mas, outrossim, também não são escassos como nas Dunas Fixas e, por isso, esta geofácie requer cuidado no que tange ao uso humano. Por fim, estas dunas também são capazes de acumular águas pluviais, recarregando, assim, os aquíferos costeiros. 


\section{Dunas Fixas}

As Dunas Fixas se distinguem das Dunas Móveis pela presença de vegetação, que ajuda a fixar o corpo de areia e auxilia na recarga do lençol freático. São formações subatuais, de geração anterior à das dunas móveis, são compostas por areias bem selecionadas, inconsolidadas, maturas, estratificadas e de origem marinha, que, assim como nas Dunas Móveis, foram transportadas pela ação dos ventos (Angelim, Medeiros e Nesi, 2006). Em Baía Formosa e algumas partes do litoral paraibano, especificamente, forma cordões que, naturalmente, são fixados por vegetação, que varia entre os portes herbáceo e arbóreo. Na porção meridional do município analisado, especialmente, a vegetação é mais exuberante, reduzindo muito os processos morfogenéticos. Vale mencionar que esta geofácie está situada na área mais chuvosa do estado do RN, sendo possível, desse modo, o seu desenvolvimento (Diniz e Pereira, 2015).

Esta geofácie foi fixada, como já salientado, pela presença da vegetação, sendo um processo natural importante da Paisagem que foi ali esculpida. Além disso, há o processo pedogenético mais intenso, que foi responsável pela formação de neossolos quartzarênicos mais desenvolvidos que aqueles presentes nas Dunas Semifixas. Todavia, a ocupação humana que se faz presente desde o século XVII também contribuiu, artificialmente, para a fixação de tais dunas.

Assim como as dunas fixas, as semi-fixas e móveis são áreas protegidas pelo Código Florestal (Brasil, 2012). Isso ocorre, pois a sua maior estabilidade depende, intrinsecamente, da presença e manutenção de sua vegetação, sendo, dessa maneira, vedadas as construções humanas, por exemplo.

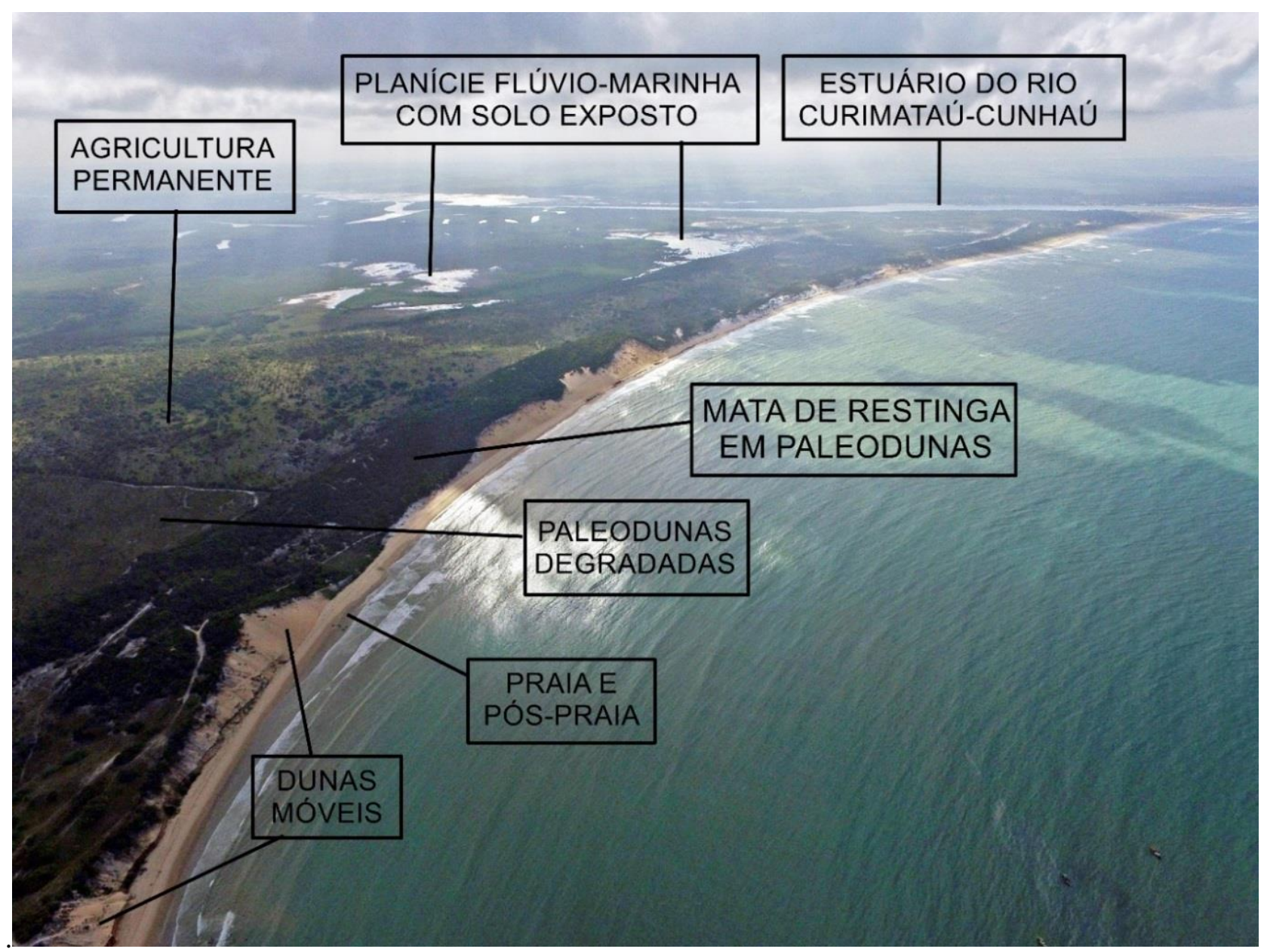

Figura 6 - Mosaico de paisagens na planície costeira do município de Baía Formosa (RN)

Praia Marinha e Pós-praia

É possível observar uma faixa contínua e praticamente retilínea de praia, o estirâncio (faixa de praia situada entre as linhas de mais alta e mais baixa maré) e o Pós-praia. As mencionadas praias são pouco desenvolvidas, planas e cujo relevo (topograficamente suave) só é alterado a partir de outras geofácies, como as Dunas já descritas. Os sedimentos presentes são areno-quarztosos, de granulação fina a grossa e bem selecionada (IDEMA, 2008). Ela é, em geral, caracterizada pela 
predominância de sedimentos quaternários, que foram retrabalhados na Formação Barreiras.

$\mathrm{Na}$ faixa praial de Baía Formosa, é comum a presença de geótopo de cinturões de Beach rocks, os quais evidenciam a mudança de linha de costa em tempos pretéritos, sempre associadas a períodos glaciais e interglaciais. Evidentemente, solos e vegetação são ausentes nesta geofácie, sendo encontrada, tão-somente, a presença de corpos de areia já na área limite com a geofácie Pós-praia.

Do ponto de vista ecodinâmico de Tricart 1977, é muito instável e de vulnerabilidade natural altíssima. Contudo, a fixação artificial de sedimentos em Baía Formosa é algo presente, em decorrência da relativamente elevada atividade turística, como no caso da praia de Sagi, gerando erosão. Os solos que se formam em virtude da ocupação humana citada são os neossolos quartzarênicos, pouco espessos, com horizonte A de poucos centímetros, antecedendo o horizonte $\mathrm{R}$.

O Pós-praia foi facilmente identificado no mapeamento e em atividades de campo. Ele forma a transição entre a Praia Marinha e as Dunas Móveis, por meio de bermas, além de formar a "linha divisória" também com a ocupação humana mais acentuada. Não dispõe de solos desenvolvidos, restringindo-se, apenas, a acumulação de sedimentos conduzidos por agentes eólicos.

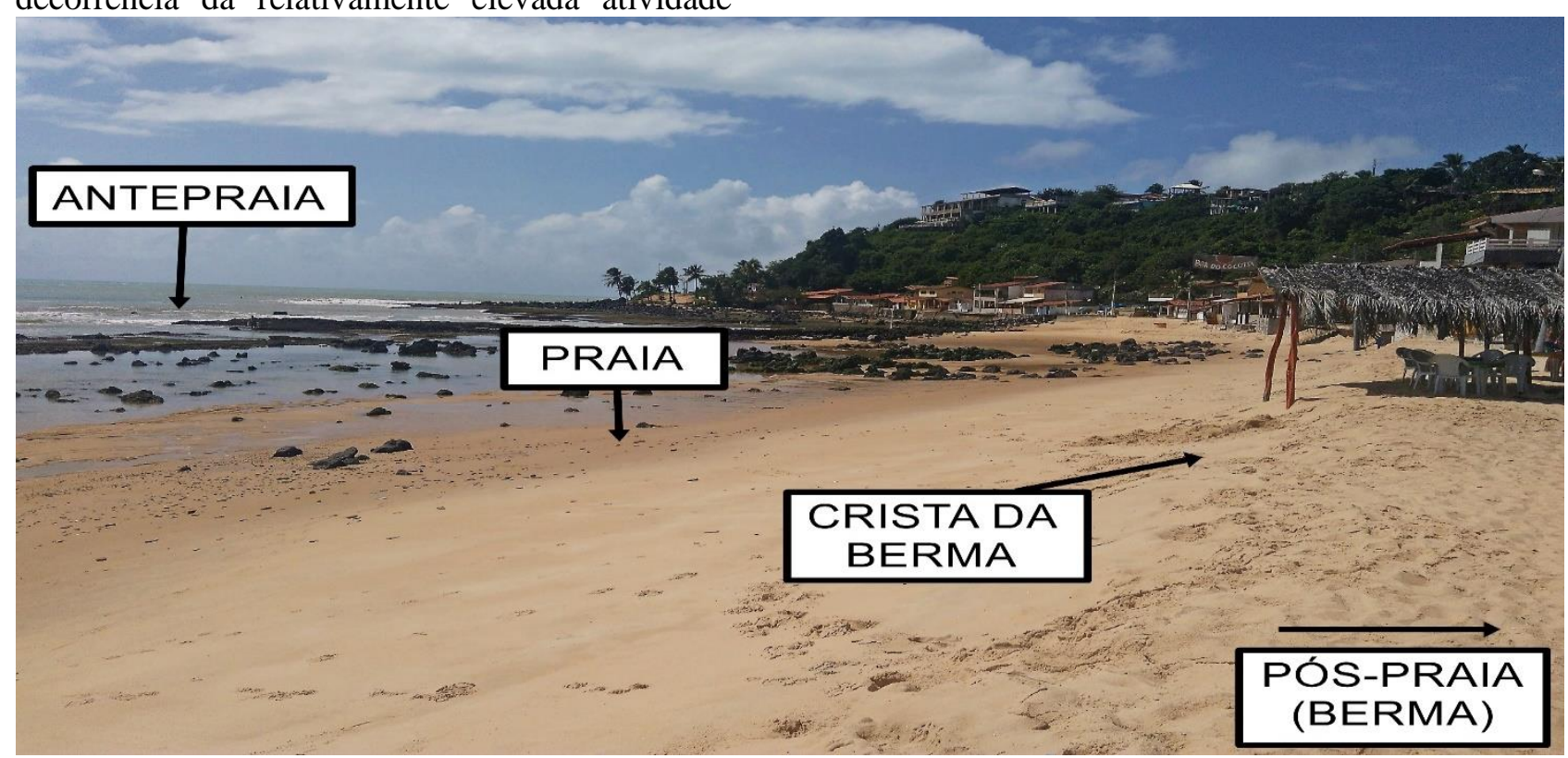

Figura 7 - Faixa praial em Baía Formosa (RN).

\section{Carcinicultura}

Esta geofácie compreende o funcionamento de viveiros de camarão, uma atividade econômica pontual no município de Baía Formosa, com cerca de uma dezena de tanques. Porém, no estuário limítrofe, mais especificamente na fronteira com Canguaretama, houve uma expansão dessa atividade, causando a degradação ambiental, com a retirada do ecossistema manguezal, gerando consequências como o aterramento do ambiente de manguezal, lançamentos de efluentes químicos e captação de água na construção de canais de abastecimento dos tanques de camarão (Silva, 2013).

\section{Edificações}

Diferentemente do que Souza 2000, e Cestaro et al. 2007, fizeram, o mapeamento presente neste artigo levou em consideração as geofácies antropizadas, pois considera a fisionomia como parâmetro norteador na delimitação de unidades da Paisagem. Assim, as áreas urbanas, foram consideradas geofácies, ao invés do que se está "por baixo", isto é, a superfície geológicogeomorfológica.

Foram mapeadas nos dois geocomplexos presentes na área, em que, a nível de organização, situam-se tanto nas Planícies quanto nos Tabuleiros Costeiros. As áreas urbanas de Baía Formosa foram facilmente identificáveis (Figura 5), a partir de seu padrão fisionômico, que é sensivelmente distinto de outras geofácies.

O mapeamento contemplou a zona urbana de Baía Formosa e pequenas comunidades e vilas na zona costeira do município, situados no Geocomplexo Planície Costeira Úmida. Entendese, aqui, a cidade como a principal construção humana, sendo importante ressaltar que ela está intimamente relacionada com a Geografia, pois contempla os aspectos do Espaço Geográfico de 
Santos 2006, bem como evidencia as rápidas, severas e eficazes modificações provocadas pelo homem.

A cidade, especificamente, foi construída sobre superfícies dunares e de pós-praia, adentrando para terrenos cobertos pela Mata Atlântica e por Mata Ciliar. Naturalmente, isso acarretou mudanças ambientais, como alteração no relevo, compactação do solo, cimentação de aquíferos, mudanças no escoamento superficial da Paisagem e, como já falado, alterações no padrão vegetacional. Destarte, a cidade é, em sua maioria, fortemente instável em seu caráter paisagístico, necessitando de um planejamento urbano mais eficaz e consoante às particularidades ambientais.

Baía Formosa possui 9.309 habitantes, segundo o IBGE (online, 2018), que, distribuídos em seu território $\left(245,6 \mathrm{~km}^{2}\right.$ ), gera uma densidade populacional pequena se comparada com áreas litorâneas de grandes atividades turísticas: 34,90 hab. $/ \mathrm{km}^{2}$.

Tabuleiros Costeiros Úmidos

Agricultura Temporária

As áreas de Agricultura Temporária estão presentes em quase todo o território de Baía Formosa e, devido ao seu caráter transitório e cíclico, necessitam de replantio todos os anos. Tais áreas são facilmente vistas em imagens de satélite, uma vez que a plantação da cana-de-açúcar se apresenta em padrões retangulares, frutos de um planejamento agrícola bem delineado e propício a terras planas ou suave onduladas como aquelas encontradas no supracitado município (Figura 8). Elas são encontradas na porção centro-oeste do município, próximas a quebra-ventos e fragmentos de mata de restinga. Além disso, faz-se necessário mencionar que as culturas temporárias de Baía Formosa são cultivadas em solos arenosos, com predominância do neossolo quartzarênico de origem recente e algumas pequenas manchas de latossolo vermelho-amarelo mais ao interior do município.

Segundo dados do IBGE 2017, o principal produto agrícola de Baía Formosa é a cana-de-açúcar, que foi cultivada em $125 \mathrm{~km}^{2} \mathrm{com}$ um total de 950.000 toneladas $(\mathrm{t})$ produzidas ao ano, sendo responsável por uma receita de R\$ 95.000,00. Outros produtos cultivados foram abacaxi, batata-doce, milho e feijão. Para Lima 2004, a importância da cana-de açúcar entre as Áreas de Agricultura Temporária não é só econômica, uma vez que esta atividade auxiliou na formação histórica do território baía-formosense.

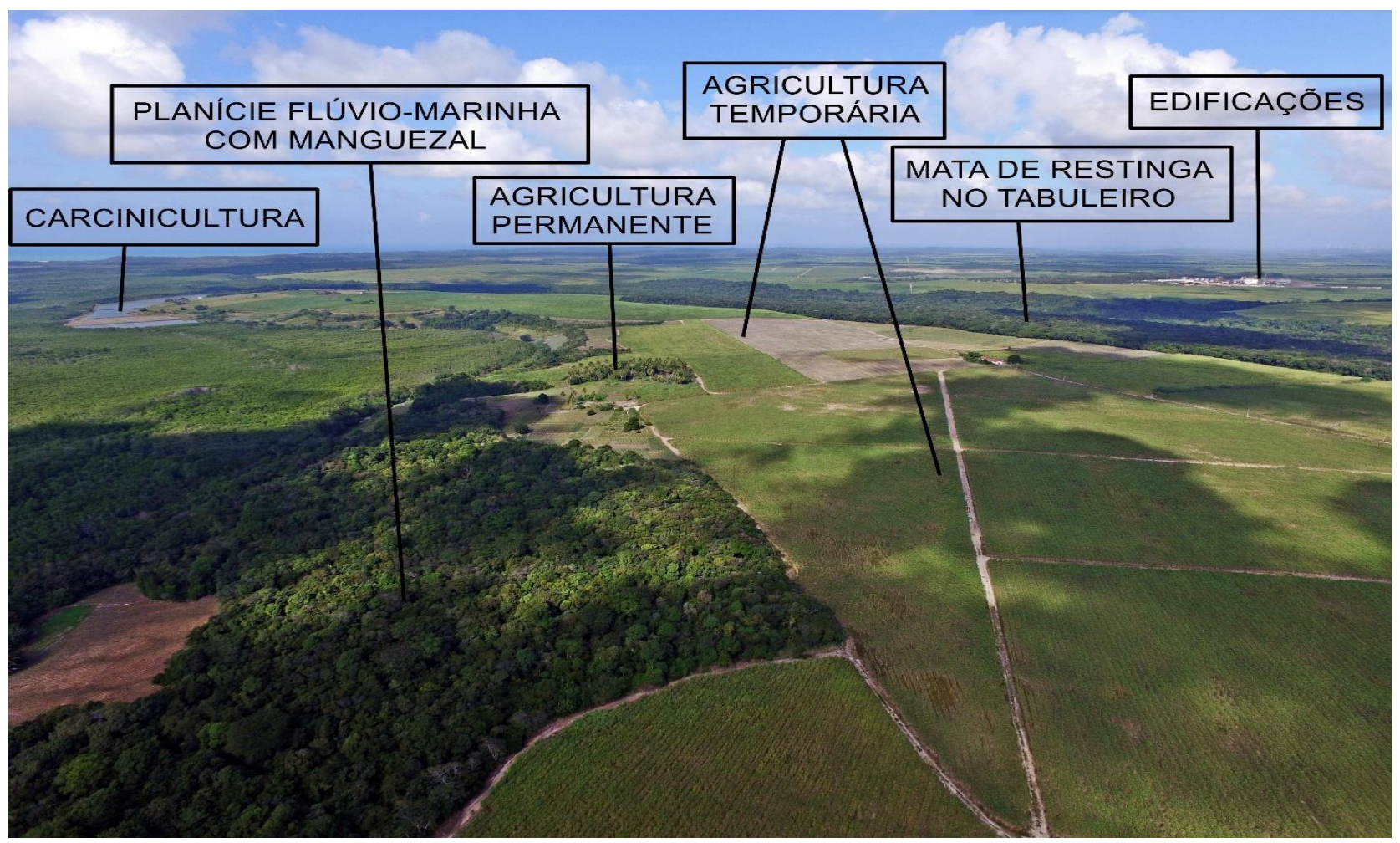

Figura 8 - Mosaico de paisagens no tabuleiro costeiro do município de Baía Formosa (RN). 
Mata de Restinga no Tabuleiro

Esta geofácie está presente a leste e sul do município às margens dos canais fluviais, em áreas com ondulações inferiores a 5\%. Como mencionado anteriormente, há uma elevada precipitação de chuvas durante o ano, tendo 3 meses secos, caracterizando o clima úmido (Diniz e Pereira, 2015), contribuindo para a estabilidade da vegetação de porte arbustivo-arbóreo na Paisagem (Figura 9). A mata se desenvolve em terrenos tabulares com predominância de latossolos amarelos bastante profundos e lixiviados que evoluíram a partir de arenitos do grupo Barreiras submetidos desde há muito ao clima úmido da área com estação chuvosa de 9 meses por ano.

\section{Agricultura Permanente}

As Áreas de Agricultura Permanente não necessitam de replantio anual, destacando-se, neste escopo, a fruticultura. São, assim, menos susceptíveis as variações climáticas que, no entanto, são menores em na região de Baía Formosa se comparada a qualquer outra parte do território potiguar.

É uma geofácie de fácil delimitação, uma vez que o plantio das culturas é realizado de maneira ordenada, retilínea, retangular e em padrões geométricos muitos semelhantes aos existentes nas áreas de Agricultura Temporária. No município, ocupa toda a parte centro-oeste, norte e sul do município, novamente não estando presente, em grande escala, na porção oriental do território. Os solos do município que apresentam textura arenosa e fertilidade natural baixa são aptos para culturas de ciclo longo como o coco-da-baía, principal expoente entre as culturas agrícolas permanentes de Baía Formosa.

Segundo dados do IBGE 2017, o cocoda-baía é o segundo principal produto agrícola de cultura permanente do município, estendendo seu cultivo por 1.200 ha que produziram 4.000.000 frutos, contribuindo em $\mathrm{R} \$ 2.360 .000,00$ para o Produto Interno Bruto (PIB) municipal. Outras culturas permanentes de menor destaque são castanha de caju, mamão e manga.

\section{Quebra-ventos}

Esta geofácie tem porte arbóreo e está distribuída no centro do município, em concomitância com a agricultura temporária, e nas adjacências, a mata de restinga (Figura 9). Por ser uma área de ventos fortes, os quebra-ventos estão presentes na paisagem de maneira perpendicular aos ventos, na perspectiva de servir como barreira, com o objetivo de proteger o cultivo da cana-deaçúcar. Além de espécies da restinga, há a presença do eucalipto que reduz a incidência de insetos e algumas pragas na cultura canavieira (França e Oliveira, 2010).

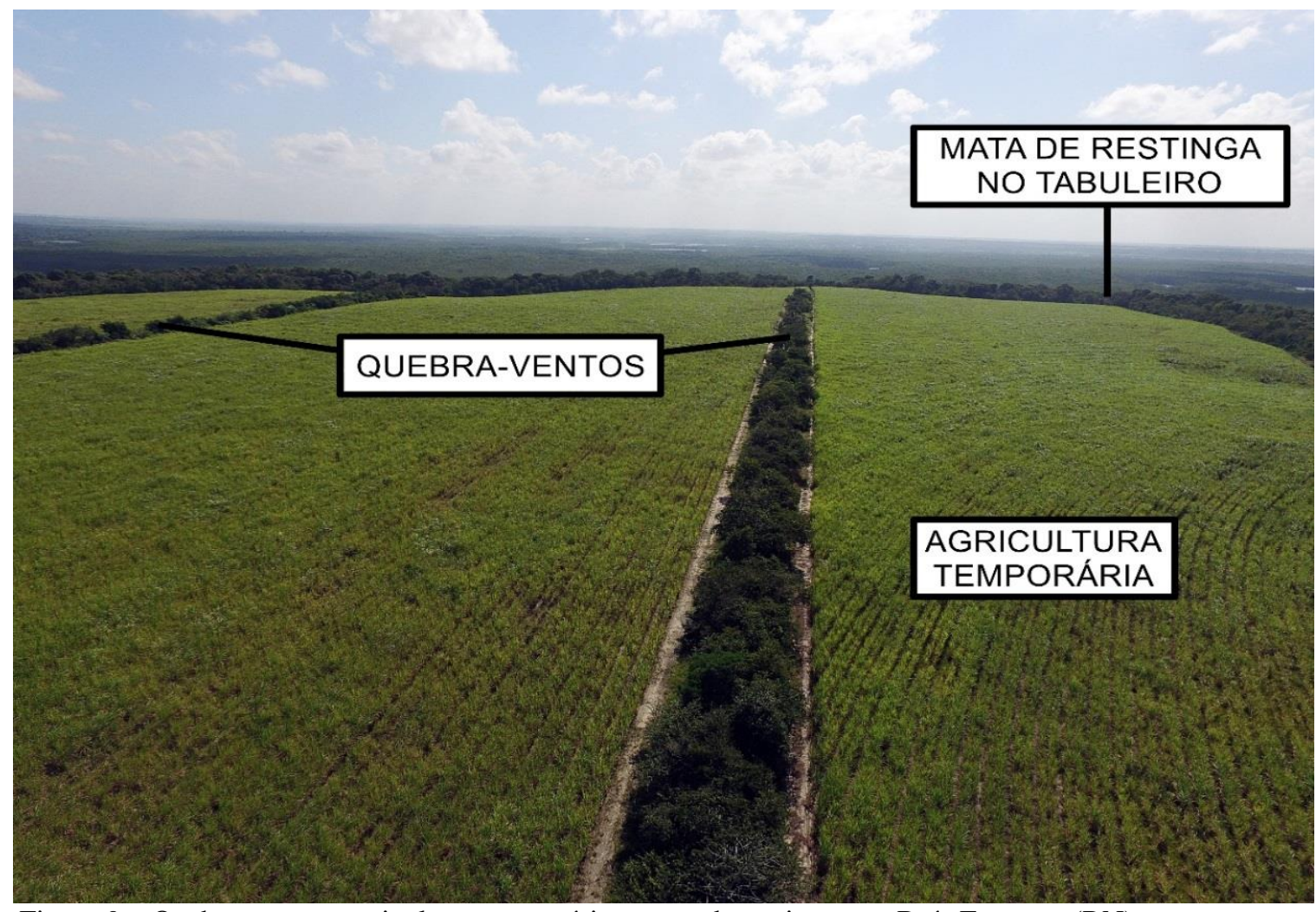

Figura 9 - Quebra-ventos, agricultura temporária e mata de restinga, em Baía Formosa (RN). 


\section{Edificações}

Como mencionado anteriormente, esta geofácie foi mapeada também no Geocomplexo tabuleiros costeiros, nos tabuleiros as edificações mapeáveis são povoados, localizados a sul, e no centro duas usinas, a Usina Vale Verde, de propriedade do Grupo Farias, que foi instalada no município em 1974 para a produção de álcool e em 2004 passou a produzir açúcar (açúcar cristal de marca Ecoçúcar). Nela, atualmente, são empregadas aproximadamente 4 mil trabalhadores, mas cerca da metade são contratados sazonalmente no período de safra, devido a sua posição geográfica estratégica que possibilita a exportação de etanol pelo porto de Cabedelo e a de açúcar pelo Porto de Natal, e a termoelétrica Usina Bio Formosa que utiliza energia elétrica através da queima do bagaço e da palha da cana-de-açúcar para gerar energia para a Usina Vale Verde (Govindin, 2014; Grupo Farias, 2018).

\section{Considerações finais}

Este trabalho buscou, por meio de uma metodologia já consagrada, efetuar a análise integrada da paisagem do município de Baía Formosa (RN), por meio de suas características fisionômicas.

Desse modo, foi realizada a hierarquização da compartimentação das paisagens desde as unidades superiores, até as inferiores, as quais foram delimitadas, a partir deste trabalho, quinze geofácies, descritas, analisadas e relacionadas de acordo com a fidelidade de suas características em escala de 1:25.000.

As características exploradas e analisadas (superfície geológica, relevo, solos, hidrografia, clima, biogeografia e aspectos relativos à ação humana de uso do solo) buscaram ser interpretadas a partir de suas múltiplas interconexões físicas e socioambientais, as quais fornecem subsídios para o apontamento de fragilidades, vulnerabilidades, peculiaridades e potencialidades de cada unidade de paisagem devidamente mapeada. Isso ocorre, pois a concepção sistêmica, trabalhada ao longo deste estudo, busca se distanciar de análises "separadas" ou que não demonstrem qualquer conexão entre elementos que, a princípio, já estão conectados em suas concepções primeiras.

Em outras palavras, o mapeamento impresso e discutido nestas laudas foi executado a partir de critérios fisionômicos, os quais empregaram, em sua análise, os aspectos sistêmicos inerentes à metodologia utilizada e já mencionada.

Por fim, cabe ressaltar que este trabalho faz parte da continuidade de uma pesquisa a nível estadual, que tem como objetivo delimitar unidades de paisagem a nível das geofácies do RN e, por essa razão, ainda possui limitações. Entretanto, crê-se que tais limitações não são suficientes para eliminar as válidas contribuições que um trabalho desse porte pode proporcionar para aqueles que querem aprender um pouco mais sobre a análise sistêmica na delimitação de unidades da Paisagem, particularmente em Baía Formosa.

\section{Agradecimentos}

O presente trabalho foi realizado com apoio da Coordenação de Aperfeiçoamento de Pessoal de Nível Superior (CAPES) e do Laboratório de Geoprocessamento e Geografia Física do Centro de Ensino Superior do Seridó CERES, da Universidade Federal do Rio Grande do Norte (LAGGEF/UFRN).

\section{Referências}

Ab'sáber, A. N, 2003. Os Domínios de Natureza do Brasil: potencialidades paisagísticas. São Paulo, Ateliê Editorial.

Angelim, L. A. A.; Medeiros, V. C.; Nesi, J. R, 2006. Programa Geologia do Brasil - PGB. Projeto Geologia e Recursos Minerais do Estado do Rio Grande do Norte. Recife, CPRM/FAPERN. 1 mapa colorido. Escala 1: 500.000 .

Bertrand, G, 1972. Paisagem e Geografia Física global: esboço metodológico. Cruz, O. (trad.) Cadernos de Ciências da Terra. São Paulo: USPIGEOG, n. 43.

Bertrand, G. 2004. Paisagem e Geografia Física global: esboço metodológico. Revista RA'E GA, Curitiba, 8, 141-152.

Bertrand, G.; Bertrand, C, 2007. Uma Geografia transversal e de travessias: o meio ambiente através dos territórios e das temporalidades. Maringá: Massoni.

Bolós, M. I. C, 1981. Problemática actual de los estudios de paisaje integrado. Revista de Geografia. Barcelona, 15, 45-68.

Brasil, 1981. Ministério das Minas e Energia. Secretaria-Geral, Projeto RADAMBRASIL. Folhas SB. 24/25 Jaguaribe/Natal; geologia, geomorfologia, pedologia, vegetação e uso potencial da terra. Rio de Janeiro.

. Lei $\mathrm{n}^{\circ} 12.651$, de 25 de maio de 2012. Código Florestal. Disponível em: < http://www.planalto.gov.br/ccivil_03/_ato2011 -2014/2012/lei/l12651.htm >. Acesso em: 20 nov. 2018.

Cailleaux, A.; Tricart, J, 1956. Le problème de la classification des faits géomorphologiques. Annalles de Géographie, 65, 162 -186.

Cestaro, L. A.; Araújo, P. C.; Medeiros, C. N.; Cisneiros, R.; Araújo, L. P, 2007. Proposta de 
um sistema de unidade geoambientais para o Rio Grande do Norte. In: Simpósio Brasileiro de Geografia Física Aplicada, Natal. Anais.

Christofoletti, A, 1999. Modelagem de sistemas ambientais. São Paulo: Edgard Büchler.

Costa, D. F. S, 2017. Serviços ecossistêmicos prestados pelos manguezais do Rio Grande do Norte (Nordeste do Brasil). Os Desafios da Geografia Física na Fronteira do Conhecimento, 1, 1127-1136.

Diniz, M. T. M.; Oliveira, A. V. L. C, 2018. Mapeamento das unidades de paisagem do Estado do Rio Grande do Norte, Brasil. Boletim Goiano de Geografia (Online). Goiânia, 38, 342-364.

Diniz, M. T. M.; Oliveira, G. P, 2016. Proposta de compartimentação em mesoescala para o litoral do nordeste brasileiro. Revista Brasileira de Geomorfologia, 17, 565-590.

Diniz, M. T. M.; Oliveira, G. P.; Medeiros, D. B. S, 2015. Proposta de classificação das paisagens integradas. REGNE, Caicó, 1, 50 - 65

Diniz, M. T. M.; Oliveira, G. P.; Maia, R. P.; Ferreira, B, 2017. Mapeamento Geomorfológico do estado do Rio Grande do Norte. Revista Brasileira de Geomorfologia, 18, 689-701.

Diniz, M. T. M.; Pereira, V. H. C, 2015. Climatologia do estado do Rio Grande do Norte, Brasil: Sistemas Atmosféricos Atuantes e Mapeamento de Tipos de Clima. Boletim Goiano de Geografia (Online), 35, 488-506.

Diniz, M. T. M.; Silva, S. D. R, 2018. O Método Indutivo e a pesquisa em Geografia: aplicação no mapeamento de unidades da Paisagem. Caderno de Geografia, 28, 731-745.

Dorado, A.; Melero, M. G.; Gomes, E. P. C.; Damato, M.; Cavana, D, 2006. Unidades de vegetação da Mata Estrela, município de Bahia Formosa - RN. In: Simpósio Regional de Geoprocessamento e Sensoriamento Remoto, 3., 2006, Aracaju. Anais.

EMBRAPA. Empresa Brasileira De Pesquisa Agropecuária, 2013. Sistema brasileiro de classificação de Solos. Brasília.

Fernandes, R. C, 2006. Diagnóstico geoambiental com uso do geoprocessamento visando a determinação de potencialidades de uso do solo para a área estuarina do Rio Curimataú Canguaretama (RN). Dissertação (Mestrado em Recursos Minerais; Recursos Hídricos; Meio Ambiente) - Universidade Federal do Rio Grande do Norte, Natal.

França, F. M. C.; Oliveira, J. B, 2010. Quebraventos na propriedade agrícola. Cartilhas temáticas - tecnologias e práticas hidroambientais para convivência com o Semiárido, Fortaleza, CE, 21p.

GRUPO FARIAS. Disponível em: < http://www.grupofarias.com.br/grupofarias/uni d_bformosa.htm >. Acesso em: 15 nov. 2018.

Govindin, J. L. S, 2014. Agroindústria canavieira e unidade de conservação: Impactos Sociais na comunidade de pescadores de Baía Formosa (RN). Dissertação (Mestrado em Meio Ambiente, Cultura e Desenvolvimento) Universidade Federal do Rio Grande do Norte, Natal.

IDEMA. Instituto de Desenvolvimento Sustentável e Meio Ambiente, 2008. Perfil do seu município. Natal.

ICMBio. INSTITUTO CHICO MENDES DE CONSERVAÇÃO DA BIODIVERSIDADE, 2018. Reservas Particulares do Patrimônio Natural - RPPN, RPPN MATA ESTRELA. Disponível em: < http://sistemas.icmbio.gov.br/simrppn/publico/ detalhe/308/ >. Acesso em 17 jul. 2018.

IBGE. INSTITUTO BRASILEIRO DE GEOGRAFIA E ESTATÍSTICA - IBGE, 2018. Produção Agrícola - Lavoura Temporária, 2017. Disponível em: < https://cidades.ibge.gov.br/brasil/rn/baiaformosa/pesquisa/14/10193 >. Acesso em 01 ago. 2018.

. Produção Agrícola - Lavoura Permanente, 2017. Disponível em: < https://cidades.ibge.gov.br/brasil/rn/baiaformosa/pesquisa/15/11863 >. Acesso em 20 nov. 2018.

Panorama - Baía Formosa. Disponível em: < https://cidades.ibge.gov.br/brasil/rn/baiaformosa/panorama >. Acesso em 01 ago. 2018.

Junk, W. J.; Piedade, M. T. F.; Lourival, R.; Wittmann, F; Kandus, P.; Lacerda, L. D.; Bozelli, R. L.; Esteves, F. A.; Nunes Da Cunha, C.; Maltchik, L.; Schöngart, J.; Schaeffernovelli, Y.; Agostinho, A. A.; Nóbrega, R. L. B.; Camargo, E, 2015. Definição e Classificação das Áreas Úmidas (AUss) Brasileiras: Base Científica para uma Nova Política de Proteção e Manejo Sustentável. In: NUNES DA CUNHA, C.; PIEDADE, M. T. F.; JUNK, W. J. (Org.) Classificação e Delineamento das Áreas Úmidas Brasileiras e de seus Macrohabitats. Cuiabá: EdUFMT, 1382.

Lima, C. J. C, 2004. Entre o Mar e a Estrela, um Lugar para se Bem Viver: a problemática da expansão urbana da cidade de Baía Formosa/RN. Dissertação (Mestrado em Geografia). Programa de Pós-Graduação em 
Arquitetura e Urbanismo, Universidade Federal do Rio Grande do Norte, Natal.

Marques Neto, R. A, 2008. abordagem sistêmica e os estudos geomorfológicos: algumas interpretações e possibilidades de aplicação. Geografia, 17, 67-87.

Morais, M. C. C, 1998. Terras Potiguares. Natal: Dinâmica.

Oliveira, F. F. G, 2011. Aplicação das técnicas de geoprocessamento na análise dos impactos ambientais e na determinação da vulnerabilidade ambiental no litoral sul do Rio Grande do Norte. Doutorado (Tese em Geociências e Meio Ambiente). Programa de Pós-Graduação em Geociências e Meio Ambiente, Universidade Estadual Paulista, Rio Claro/SP

Panizza, A. C.; Fonseca, F. P, 2011. Técnicas de interpretação visual de imagens. GEOUSP Espaço e tempo, São Paulo, 30-43.

Ross, J. L. S, 2009. Ecogeografia do Brasil: subsídios para planejamento ambiental. São Paulo: Oficina de Textos.

Santos, M, 2006. A natureza do espaço: técnica e tempo, razão e emoção. 4. ed. $2^{\mathrm{a}}$ reimpr. São Paulo: Edusp. 384 p. (Coleção Milton Santos, 1).

Silva, F. M, 2013. Análise da vulnerabilidade ambiental no estuário do Rio Curimataú/Cunhaú, Baía Formosa e Canguaretama - RN. Dissertação (Mestrado em Dinâmica e Reestruturação do Território) Universidade Federal do Rio Grande do Norte, Natal.
Silva, S. D. R, 2018. Delimitação de Unidades da Paisagem do Litoral Setentrional Potiguar e Adjacências. Dissertação (Mestrado em Geografia). Programa de Pós-Graduação e Pesquisa em Geografia, Universidade Federal do Rio Grande do Norte, Natal.

Soares, A. M. C, 2013. Gestão ambiental no turismo: uma análise dos Impactos Ambientais nos atrativos turísticos de Baía Formosa/RN. Monografia (Graduação em Turismo) Universidade Federal do Rio Grande do Norte, Natal.

Sochava, V. B, 1963. The Definition of Some Concepts and Terms in Physical Geography, Dokl. In-ta geografii Sibiri i Dal'nego Vostoka, 50-59.

Souza, A. C. D.; Oliveira, A.M.; Costa, D. F. S, 2017. Classificação das áreas úmidas no sistema estuarino Galinhos e Guamaré (RN). In: Simpósio Brasileiro de Geografia Física Aplicada, 17, 2017, Campinas, SP. Anais... Campinas: UNICAMP, 1172-1180.

Souza, F. E. S, 2004. Evolução morfodinâmica da região de influência estuarina do Rio Curimataú/RN, com ênfase nas alternativas do ambiente deposicional de manguezal e a integração de geodados em Sig. Tese (Doutorado em Geodinâmica e Geofísica) Universidade Federal do Rio Grande do Norte, Natal.

Souza, M. J. N, 2000. Bases Naturais e Esboço do Zoneamento Geoambiental do Estado do Ceará. In: LIMA, L. C., SOUZA, M. J. N., MORAIS, J. O. Compartimentação Territorial e Gestão Regional do Ceará. Fortaleza, Funece.

Tricart, J, 1977. Ecodinâmica. Rio de Janeiro: IBGE, SUPREN, 97. 